\title{
Analisis Pembelajaran Daring Matematika pada Siswa Kelas XII IPA SMA Negeri 7 Mataram
}

\author{
Mutala'ah $^{1}$, Arjudin $^{2}$, Wahidaturrahmi², Sudi Prayitno ${ }^{2}$ \\ ${ }^{1}$ Mahasiswa Pendidikan Matematika, FKIP, Universitas Mataram, Mataram \\ ${ }_{2}^{2}$ Pendidikan Matematika, FKIP, Universitas Mataram, Mataram \\ mutalaah12@gmail.com
}

Diterima: 13-12-2021; Direvisi: 20-12-2021; Dipublikasi: 30-12-2021

\begin{abstract}
This study aims to describe the online mathematics learning process and to find out the mathematics learning outcomes in terms of the mathematics disposition of class XII IPA students at SMA Negeri 7 Mataram. This type of research is descriptive qualitative. All students of class XII IPA at SMA Negeri 7 Mataram are the population, where the sample size is 62 students who were selected by cluster random sampling rule. Data collection used a questionnaire, interview and documentation study. From this research, the results show that: (1) The learning process carried out by the teacher changes from direct learning to online learning. In the online learning process, there are several difficulties experienced by students, including students who do not understand the material presented by the teacher, whether the material is delivered in the form of a pdf or video that has been shared. In implementing the online learning process the teacher is not the only source of learning so students are actively looking for other learning reference sources such as videos on YouTube and websites. Assessment of learning outcomes is carried out by providing a written test of the test resulting in that there is no increase in student learning outcomes during learning with an online system. The implementation of online learning cannot be separated from the supervision of parents and teachers. (2) There is a correlation between final semester test scores with students' mathematical dispositions.
\end{abstract}

Keywords: online learning; learning outcomes; mathematical disposition

\begin{abstract}
Abstrak
Penelitian ini bertujuan untuk mendeskripsikan proses pembelajaran daring matematika dan mengetahui hasil belajar matematika ditinjau dari disposisi matematika siswa kelas XII IPA di SMA Negeri 7 Mataram. Jenis penelitian yakni deskriptif kualitatif. Seluruh siswa kelas XII IPA di SMA Negeri 7 Mataram merupakan populasi, dimana jumlah sampel 62 siswa yang dipilih dengan aturan cluster random sampling. Pengumpulan data menggunakan angket, wawancara dan studi dokumentasi. Dari penelitian ini diperoleh hasil bahwa: (1) Proses pembelajaran yang dilaksanakan guru berubah dari pembelajaran langsung menjadi pembelajaran dalam jaringan. Dalam proses pembelajaran daring ada beberapa kesulitan yang dialami siswa diantaranya siswa kurang memahami materi yang disampaikan oleh guru baik materi yang disampaikam dalam bentuk pdf atau video yang telah dibagikan. Dalam pelaksanaaan proses pembelajaran daring guru bukan merupakan sumber belajar satu-satunya sehingga siswa aktif mencari sumber referensi belajar yang lain seperti video di youtube dan website. Penilaian hasil belajar dilakukan dengan memberikan tes tertulis dari tes tersebut dihasilkan bahwa tidak terdapat peningkatan hasil belajar siswa selama mengikuti pembelajaran dengan sistem daring. Terlaksananya pembelajaran daring tidak terlepas dari pengawasan orangtua dan guru. (2) Terdapat korelasi antara nilai ulangan akhir semester dengan disposisi matematika siswa.
\end{abstract}

Kata Kunci: pembelajaran dalam jaringan; hasil belajar; disposisi matematika 


\section{PENDAHULUAN}

Matematika memegang peranan yang penting dalam kehidupan manusia. Kemajuan sains dan teknologi yang begitu pesat dewasa ini tidak lepas dari peranan matematika. Mengingat pentingnya peranan matematika, maka matematika menjadi salah satu mata pelajaran pokok yang diajarkan pada setiap jenjang pendidikan dari mulai SD, SMP, SMA, sampai Perguruan Tinggi (Karim, 2011).

Dalam pembelajaran matematika, guru berperan sebagai manajer dari sistem pemberdayaan. Kerjasama yang harmonis antara guru dan siswa dalam melakukan berbagai kegiatan belajar akan memberikan hasil belajar yang optimal. Mappeasse (2009) berpendapat bahwa, "Hasil belajar adalah kemampuan yang dimiliki baik bersifat pengetahuan (kognitif), sikap (afektif), maupun keterampilan (psikomotorik) yang semuanya ini diperoleh melalui proses belajar mengajar." Terdapat beberapa strategi dalam mengoptimalkan hasil belajar, salah satunya adalah dengan menggunakan media pembelajaran. Menurut Mustaqim (2016) menyatakan bahwa media pembelajaran merupakan kunci antara guru dan siswa dalam berkomunikasi secara optimal, dikarenakan media pembelajaran adalah alat bantu, alat penyalur, alat penguat dan wakil guru untuk menyampaikan informasi secara teliti, jelas dan menarik.

Namun permasalahannya, saat ini sistem pendidikan dihadapkan dengan situasi yang menuntut para pengajar untuk dapat menguasai media pembelajaran jarak jauh, terutama pada masa wabah pandemi Covid-19. Solusi yang dapat dilakukan di masa pandemi ini yaitu dengan melakukan pembelajaran daring (Syarifudin, 2020). Salah satu media pembelajaran jarak jauh yang dapat digunakan yakni media Google Classroom. Aplikasi google classroom dilengkapi dengan berbagai pilihan menu yang mendukung seperti adanya assignment, grading, communication, time-cost, archive course, mobile aplication, dan privacy. Selain dilengkapi dengan berbagai menu pilihan, penggunaan google classroom juga memberikan banyak manfaat bagi penggunanya diantaranya yaitu penyiapan yang mudah untuk dilakukan, guru dapat menambahkan siswa langsung atau berbagi kode dengan kelasnya untuk bergabung, hemat waktu, alur tugas yang sederhana dan tanpa kertas memungkinkan pengajar membuat, memeriksa dan menilai tugas dengan cepat disatu tempat (Utami, 2019). Google Classroom belakangan ini banyak digunakan para pelajar, mahasiswa, guru dan dosen sebagai media komunikasi yang terhalang oleh jarak.

Pemerintah NTB telah mengeluarkan Surat Edaran Gubernur NTB pada tanggal 7 Juli 2020 tentang Penyelenggaraan Pembelajaran di Satuan Pendidikan Tahun Pelajaran 2020/2021 di Masa Pandemi Corona Virus Disease 19. Surat tersebut memuat empat poin yang salah satunya yaitu pembelajaran di Satuan Pendidikan di Provinsi Nusa Tenggara Barat dilakukan dengan belajar dari rumah melalui sistem daring/online/luring/modul dan atau bentuk lain memanfaatkan segala sumber daya yang dimiliki secara optimal. Belajar dari rumah melalui sistem daring/online/luring/modul dan atau bentuk lain berlaku sampai dengan ditetapkan 
ketentuan kemudian. Surat Edaran Gubernur NTB tersebut diperuntukkan untuk seluruh jenjang pendidikan dari TK, SD, SMP, SMA dan Perguruan Tinggi yang berada di wilayah Kota Mataram. Dalam hal ini, peneliti melakukan penelitian pada salah satu jenjang pendidikan yaitu di SMAN 7 Mataram yang telah menerapkan proses pembelajaran daring di masa pandemi Covid-19. Adapun fokus penelitian yang dilakukan peneliti di SMAN 7 Mataram yaitu siswa kelas XII dengan dasar bahwa siswa kelas XII sudah mendapatkan pembelajaran matematika pada tahun sebelumnya yaitu saat duduk dibangku kelas X dan kelas XI.

Berdasarkan hasil wawancara yang dilakukan oleh peneliti kepada salah satu guru mata pelajaran matematika kelas XII di SMA Negeri 7 Mataram pada tanggal 4 Juli 2020, diperoleh informasi bahwa saat terjadinya pandemi Covid-19 pembelajaran beralih ke pembelajaran daring dengan menggunakan media Google Classroom. Penggunaan Google Classroom lebih familiar digunakan dalam kehidupan sehari-hari dan dianggap lebih mudah digunakan oleh guru dan siswa. Siswa sangat antusias dan bersemangat selama pembelajaran daring berlangsung.

Pada tanggal 17 Februari 2021, peneliti melakukan kunjungan ke sekolah SMAN 7 Mataram untuk mengetahui proses pembelajaran tatap muka yang telah di jadwalkan oleh skolah bagi seluruh siswa kelas XII. Sekolah menjadwalkan pembelajaran secara tatapmuka dengan tujuan persiapan menuju ulangan akhir semester dan ujian akhir sekolah untuk siswa kelas XII. Sehingga, di SMAN 7 Mataram menerapkan sistem pembelajaran secara online dan pembelajaran secara tatap muka dengan jadwal yang telah ditentukan oleh sekolah. Hasil dari kunjungan tersebut diperoleh informasi bahwa salah satu kelas XII yang ada di SMAN 7 Mataram sangat bersemangat selama mengikuti pembelajaran matematika. Materi yang telah dibagikan guru secara online melalui Google Classroom dan aplikasi WhatsApp Group dipelajari dengan baik oleh siswa. Sehingga terlihat jelas bahwa siswa dapat menjawab setiap pertanyaan dan soal yang berikan oleh guru, siswa mampu mengerjakan soal tersebut di depan kelas serta menyatakan diri mengerti dengan materi yang sedang diajarkan. Hal ini menunjukan bahwa siswa memiliki disposisi matematika yang tinggi. Akbar et al., (2018) berpendapat bahwa disposisi matematika merupakan keinginan, kesadaran, dedikasi dan kecendrungan yang kuat pada diri siswa untuk berpikir dan berbuat secara matematik dengan cara yang positif seperti percaya diri, fleksibel dalam menyelesaikan masalah.

Pembelajaran dengan sistem daring merupakan sistem baru dalam pendidikan di Kota Mataram khususnya di SMAN 7 Mataram. Sehingga perlu diadakan kajian lebih mendalam tentang sistem pembelajaran daring sebagai salah satu langkah untuk memperbaiki ssstem pendidikan di Indonesia agar dapat lebih maju. Salah satu kajian tentang proses pembelajaran daring dilakukan oleh Putria et al., (2020). Hal yang membedakan antara penelitian yang akan dilakukan peneliti dengan penelitian yang sudah dilakukan oleh Putria et al., yaitu penilitian ini bertujuan untuk mendeskripsikan proses pembelajaran daring pada matematika dan mengetahui hasil 
belajar matematika siswa kelas XII IPA di SMA Negeri 7 Mataram Semester Genap Tahun Pelajaran 2020/2021 ditinjau dari disposisi matematika yang akan dikorelasikan dengan nilai ujian akhir semester genap yang diperoleh melalui guru mata pelajaran matematika. Hasil penelitian ini diharapkan dapat menambah kekayaan ilmu dan memperkaya pengetahuan tentang pembelajaran daring dalam proses belajar mengajar.

\section{METODE PENELITIAN}

Jenis penelitian ini adalah deskriptif kualitatif. Penelitian deskriptif kualitatif digunakan untuk mengetahui fenomena yang ada dalam kondisi objek yang alamiah, bukan dengan kondisi terkendali, laboratories atau eksperimen (Sugiyono, 2014). Penelitian ini dilaksanakan di SMAN 7 Mataram pada tanggal 6 sampai 10 April 2021.

Populasi dalam penelitian ini adalah seluruh siswa kelas XII IPA di SMA Negeri 7 Mataram berjumlah 195 siswa yang terdiri dari 6 kelas dengan sampel dalam penelitian ini adalah siswa kelas XII IPA 5 dan XII IPA 6 di SMA Negeri 7 Mataram yang dipilih dengan aturan cluster random sampling.Untuk memperoleh informasi lebih mendalam tentang proses pembelajaran daring dipilih 3 siswa dengan kemampuan tinggi, sedang dan rendah dengan pertimbangan berdasarkan hasil ulangan akhir semester yang diperoleh dari guru.

Instrumen yang digunakan yaitu angket proses pembelajaran daring matematika, angket disposisi matematika dan pedoman wawancara. Uji validitas yang digunakan adalah validitas ahli dengan bantuan 5 orang ahli dalam hal ini 2 dosen pendidikan matematika FKIP Unram dan 3 guru matematika SMAN 7 Mataram sebagai validator.

Untuk menghitung validitas berdasarkan validitas Aiken's digunakan rumus berikut:

$$
V=\frac{\sum s}{[n(c-1)]}
$$

(Azwar, 2017:113)

$$
\begin{aligned}
& \text { Keterangan: } \\
& \begin{array}{l}
\mathrm{V}=\text { Indeks Validitas Aiken's } \\
\mathrm{s}=\mathrm{r} \text {-lo } \\
\mathrm{r}=\text { Angka yang diberikan Validator } \\
\mathrm{lo}=\text { Angka penilaian validitas terendah } \\
\mathrm{c}=\text { Angka penilaian Validitas tertinggi } \\
\mathrm{n}=\text { banyak validator }
\end{array}
\end{aligned}
$$

Setelah rata-rata validitas instrumen diperoleh selanjutnya skor tersebut diolah dan hasilnya dapat dilihat pada tabel pedoman kriteria validasi berikut: 
Tabel 1. Kriteia Penilian Aiken's V

\begin{tabular}{cc}
\hline Indeks Validitas & Kategori \\
\hline $0,80 \leq V \leq 1.00$ & Sangat Valid \\
$0,60 \leq V<0,80$ & Valid \\
$0,40 \leq V<0,60$ & Cukup Valid \\
$0,20 \leq V<0,40$ & Kurang Valid \\
$0,0 \leq \mathrm{V}<0,20$ & Tidak Valid \\
\hline
\end{tabular}

(Arikunto, 2018)

Selanjutnya, instrumen yang sudah valid digunakan untuk menjaring data proses pembelajaran daring dan disposisi matematika siswa. Data yang sudah terkumpul kemudian dianalisis, tehnik analisis data yang digunakan dalam penelitian ini yaitu Method of Successive Interval (MSI) dengan bantuan software Microsoft Excel 2007 yang dilakukan untuk mengubah data angket proses pembelajaan daring dan angket disposisi matematika dari skala data ordinal menjadi skala interval, selanjutnya menentukan skor angket proses pembelajaran daring matematika dan angket disposisi matematika siswa. Tahap kedua yaitu menentukan skor rata-rata (mean) angket proses pembelajaran daring matematika dan disposisi matematika. Selanjutnya, peneliti mengumpulkan nilai hasil ulangan akhir semester genap mata pelajaran matematika yang diperoleh dari guru matematika di SMAN 7 Mataram yang akan dipadukan dengan data angket disposisi matematika. Sementara data hasil wawancara diolah berdasarkan pendapat Miles dan Huberman (dalam Sugiyono, 2014) yaitu reduksi data, penyajian data dan penarikan kesimpulan. Wawancara dilakukan untuk menggali informasi lebih dalam tentang proses pembelajaran daring matematika.

Untuk menghitung persentase skor angket proses pembelajaran daring matematika dan disposisi matematika yang telah diperoleh, kemudian dihitung nilai persentasinya dengan rumus berikut:

Persentase skor angket $=\frac{\text { skor yang diperoleh }}{\text { skor maksimum }} \times 100 \%$

\section{HASIL DAN PEMBAHASAN}

\subsection{Proses Pembelajaran Daring di SMAN 7 Mataram}

Seluruh data proses pembelajaran daring matematika yang telah terkumpul terlebih dahulu dirubah dari data skala ordinal menjadi skala interval menggunakan MSI (Method Of Successive Interval) menggunakan bantuan microsoft excel 2007 sehingga hasil penelitian menunjukkan bahwa proses pembelajaran daring matematika pada kelas XII IPA 5 dan kelas XII IPA 6 di SMA Negeri 7 Mataram tahun pelajaran 2020/2021 memiliki mean 82,82 dengan skor maksimal 104.35 dan skor minimal 62,17. Dari hasil penelitian penentuan kategori proses pembelajaran daring matematika dan distribusi frekuensinya dapat di lihat pada tabel berikut. 
Tabel 2. Penentuan Kategori Proses Pembelajaran Daring

\begin{tabular}{cccc}
\hline Skala & Frekuensi & Frekuensi(\%) & Kategori \\
\hline$X_{1} \geq 88,73$ & 15 & $24,19 \%$ & Baik \\
$58,37 \leq X_{1}<88,73$ & 47 & $75,80 \%$ & Cukup baik \\
$X_{1}<58,37$ & 0 & $0 \%$ & Kurang \\
\hline
\end{tabular}

Berdasarkan hasil perhitungan diperoleh bahwa proses pembelajaran daring matematika di kelas XII IPA di SMA Negeri 7 Mataram dengan 69,35\% siswa mengategorikan proses pembelajaran daring baik, 9,67\% mengategorikan cukup baik dan 20,96 \% mengategorikan kurang. Selanjutnya untuk melihat ketercapaian dari masing-masing indikator proses pembelajaran daring dihitung nilai rata-rata setiap indikator proses pembelajaran daring matematika yang dapat dilihat pada tabel berikut.

Tabel 3. Data Deskriptif Indikator Proses Pembelajaran Daring

\begin{tabular}{lc}
\hline \multicolumn{1}{c}{ Indikator } & rata-rata \\
\hline Perencanaan pembelajaran & 189,96 \\
Pelaksanaan pembelajaran & 186,44 \\
Penilaian proses dan hasil belajar & 171,43 \\
Pengawasan proses pembelajaran & 177,21 \\
Melakukan evaluasi & 180,37 \\
\hline
\end{tabular}

Berdasarkan perhitungan dapat dilihat bahwa rata-rata indikator proses pembelajaran daring tentang perencanaan pembelajaran 189,96. Sedangkan indikator pelaksanaan pembelajaran 186,44, indikator penilaian proses dan hasil belajar 171,43. Selanjutnya indikator pengawasan proses pembelajaran 177,21 dan terakhir indikator melakukan evaluasi 180,37.

Untuk menggali informasi lebih dalam terkait proses pembelajaran daring matematika, peneliti melakukan wawancara terhadap 3 siswa dengan kriteria 1 siswa berkemampuan tinggi, 1 siswa berkemampuan sedang dan 1 siswa berkemampuan rendah yang dipilih berdasarkan nilai ulangan akhir semester genap yang diperoleh dari guru. Subjek penelitian yang terpilih yaitu S62, S30 dan S55.

Data dari hasil belajar yang diperoleh dari guru mata pelajaran matematika menunjukkan bahwa hasil belajar maatematika dengan sistem daring pada kelas XII IPA 5 dan kelas XII IPA 6 di SMA Negeri 7 Mataram tahun pelajaran 2020/2021 dapat dilihat pada tabel berikut: 
Tabel 4. Hasil Belajar Matematika

\begin{tabular}{lc}
\hline \multicolumn{2}{c}{ Keterangan Nilai } \\
\hline Total Nilai & 4330 \\
Nilai tertinggi & 84 \\
Nilai terendah & 48 \\
Nilai rata-rata & 68,73 \\
Ketuntasan belajar klasikal & 29,03 \\
Jumlah siswa yang tuntas & 18 \\
Jumlah siswa yang tidak tuntas & 44 \\
Jumlah siswa & 62 \\
\hline
\end{tabular}

Pada tabel 4.3 di atas diperoleh informasi ketuntasan belajar siswa. Berdasarkan petunjuk pelaksanaan belajar mengajar pada tingkat satuan pendidikan di SMAN 7 Mataram, seorang siswa telah tuntas belajar matematika bila telah mencapai skor yang telah ditetapkan dalam kriteria ketuntasan minimal (KKM) yaitu telah mencapai nilai lebih dari atau sama dengan 75. Untuk mnghitung prosentase ketuntasan belajar klasikal digunakan rumus sebagai berikut:

$$
\begin{aligned}
& \text { \% belajar siswa }=\frac{\text { Siswa yang tntas belajar }}{\text { jumlah siswa }} \times 100 \\
& P=\frac{18}{62} \times 100 \\
& P=29,03 \%
\end{aligned}
$$

Berdasarkan tabel diatas dapat dikemukakan bahwa dari 62 orang siswa kelas XII IPA 5 dan XII IPA 6 SMAN 7 Mataram diperoleh skor total 4330 dengan rata-rata 68,73. Dari data tersebut yang memenuhi standar KKM (75) dapat diketahui hanya 18 siswa dari 62 siswa, selebihnya 44 siswa tidak tuntas.

Dari hasil penelitian penentuan kategori hasil belajar daring matematika yang diperoleh dari guru dan distribusi frekuensinya dapat di lihat pada tabel berikut.

Tabel 5. Penentuan Kategori Hasil Belajar Matematika

\begin{tabular}{cccc}
\hline Skala & Frekuensi & Frekuensi(\%) & Kategori \\
\hline$Y_{1} \geq 75$ & 23 & $37,09 \%$ & Tinggi \\
$50 \leq Y_{1}<75$ & 35 & $56,45 \%$ & Sedang \\
$Y_{1}<50$ & 4 & $6,45 \%$ & Rendah \\
\hline
\end{tabular}

Berdasarkan hasil perhitungan diatas, dapat disimpulkan bahwa hasil belajar daring matematika siswa kelas XII IPA di SMAN 7 Mataram dengan 37,09\% tergolong tinggi, 56,45\% tergolong sedang dan 6,45\% tergolong rendah. Hal ini menunjukkan bahwa sebagaian besar siswa kelas XII IPA di SMAN 7 Mataram semester genap tahun pelajaran 2020/2021 memiliki hasil belajar yang tinggi dan sedang. 
Sementara angket disposisi matematika pada kelas XII IPA 5 dan kelas XII IPA 6 di SMA N 7 Mataram memiliki mean 80,83 dengan skor yang diperoleh maksimal 103.99 dan skor minimal 58,43. Dari hasil penelitian penentuan kategori hasil belajar daring matematika dan distribusi frekuensinya dapat di lihat pada tabel berikut.

Tabel 6. Penentuan Kategori Angket Disposisi Matematika

\begin{tabular}{cccc}
\hline Skala & Frekuensi & Frekuensi(\%) & Kategori \\
\hline$X_{2} \geq 80,72$ & 31 & $50,00 \%$ & Tinggi \\
$52,92 \leq X_{2}<80,72$ & 31 & $50,00 \%$ & Sedang \\
$X_{2}<52,92$ & 0 & $0 \%$ & Rendah \\
\hline
\end{tabular}

Berdasarkan hasil perhitungan diatas, dapat disimpulkan bahwa hasil belajar daring matematika siswa kelas XII IPA di SMAN 7 Mataram dengan 50\% tergolong tinggi, dan $50 \%$ tergolong sedang. Selanjutnya untuk mengetahui sejauh mana keberhasilan dari masing-masing indikator dilakukan perhitungan untuk mengetahui rata-rata setiap indikator angket hasil belajar matematika yang dapat dilihat pada tabel berikut.

Tabel 7. Rata-rata Indikator Hasil Belajar Matematika

\begin{tabular}{lc}
\hline \multicolumn{1}{c}{ Indikator } & Mean \\
\hline Percaya diri dalam menggunakan matematika & 192.40 \\
Fleksibel dalam menyelesaikan masalah matematika & 187.00 \\
Gigih dan ulet dalam mengerjakan tugas-tugas matematika & 202.51 \\
Memiliki rasa ingin tahu dalam matematika & 207.04 \\
Mengapresiasi peranan matematika & 214.12 \\
\hline
\end{tabular}

Berdasarkan tabel diatas, dapat dilihat bahwa rata-rata indikator disposisi matematis siswa tentang percaya diri dalam menggunakan matematika 192,40 sedangkan indikator fleksibel dalam menyelesaikan masalah matematika 187,00, indikator gigih dan ulet dalam mengerjakan tugas-tugas matematika 202,51. Selanjutnya untuk indikator memiliki rasa ingin tahu dalam matematika 207,04 dan terakhir indikator mengapresiasi peranan matematika 214,12.

Berdasarkan hasil perhitungan rata-rata maka dapat disimpulkan bahwa proses pembelajaran daring pada siswa kelas XII IPA SMA N 7 Mataram tahun pelajaran 2020/2021 secara umum pada kategori baik dimana sebanyak 15 orang dengan persentase $24,19 \%$, frekuensi siswa yang menganggap proses pembelajaran daring pada kategori cukup baik sebnyak 47 orang dengan persentase 75,80\%, dan pada tidak ada siswa yang mengategorikan kurang. Hasil analisis deskriptif unuk setiap indikator proses pembelajaran daring menunjukan bahwa dari segi rata-rata, indikator perencanaan pembelajaran paling tinggi yaitu 189,96. Dilihat dari jawaban yang diberikan oleh siswa pada butir-butir pernyataan angket tentang pembelajaran daring menunjukan bahwa pembelajaran daring dilaksanakan sesuai dengan jam pembelajaran yang sebelumnya sudah ditentukan. Hal ini sejalan dengan Widyaningrum et al., (2020) mengatakan bahwa penyususunan jadwal pembelajaran sangat dibutuhkan agar pembelajaran berjalan sesuai dengan yang telah direncanakan. 
Penyususnan jadwal pelajaran disesuaikan dengan tenaga pendidik juga memperhatikan kefektifan belajar. Pada pelaksaaan pembelajaran daring atau online di sekolah dengan pembelajaran regular memiliki perbedaan yang signifikan, diantara perbedaan tersebut yang sangat terlihat yaitu kegiatan pembelajaran dilaksanaakan secara virtual yaitu di rumah masing-masing siswa. Pembelajaran daring yang dilaksanakan oleh guru mata pelajaran matematika di SMAN 7 Mataram menggunakan whatsapp dan google classroom yang digunakan sebagai media guru dalam menyampaikan materi atau mengirimkan tugas kepada siswa.

Perencanaan pembelajaran posisi kedua yaitu 189,96. Besarnya rata-rata skor ini menunjukan bahwa perencanaan pembelajaran yang dilakukan oleh guru saat pembelajaran daring berlangsung berdasarkan tabel 4.1 memilki arti bahwa pembelajaran yang telah dirancang oleh guru belum mapan dan maksimal. Hal ini sejalan dengan Bararah (2017) yang menyatakan bahwa perencanaan sangat dibutuhkan sebelum pelaksanaan proses pembelajaran dilaksanakan, hal tersebut diperuntukkan agar proses pembelajaran tersusun dan terarah sesuai dengan tujuan yan diinginkan. Tanpa perencanaan yang matang, sulit mencapai target pembelajaran dengan maksimal. Salah satu faktor penting berhasilnya proses pembelajaran di kelas adalah dengan adanya perencanaan pembelajaran yang matang.

Indikator penilaian proses dan hasil belajar menempati posisi ketiga dengan nilai ratarata yaitu 171,43. Berdasarkan data tersebut penilaian proses dan hasil belajar perlu ditingkatkan agar guru ataupun orangtua mengetahui sejauh mana perkembangan yang telah dicapai oleh siswa. Hal ini sejalan dengan (Ani, 2013) mengemukakan bahwa penilaian merupakan bagian penting dari sebuah pembelajaran. Penilaian berfungsi untuk mengukur sejauh mana siswa dapat mencapai tujuan-tujuan pembelajaranyang telah ditetapkan.

Indikator pengawasan proses pembelajaran berada pada posisi keempat dengan nilai rata-rata 177,21 . perlu adanya peningkatan pengawasan pada proses pembelajaran di sekolah agar proses pembelajaran berjalan dengan lancer. Bukan hanya guru dan kepala sekolah, pengawasan dalam pmbelajaran di lakukan juga oleh orang tua siswa untuk memberikan perhatian dan dorongan kepada anaknya agar tercapainya tujuan pembelajaran yang diharapkan. Pengawasan sekolah itu penting karena merupakan mata rantai terakhir dan kunci dari proses manajemen.

Indikator melakukan evaluasi menempati posisi terakhir dengan rata-rata 180,37. Artinya evaluasi yang dilakukan oleh guru belum dilakukan dengan maksimal. Belum maksimalnya evaluasi yang dilakukan salah satunya dipengaruhi oleh cara guru melakukan evaluasi itu sendiri. Kenyataannya yang terjadi dalam proses pembelajaran matematika bahwa jika tidak ada konsekuensi tugas harus dikumpulkan maka akan ada sebagian kecil yang akan mengerjakan tugas dan berlaku juga untuk sebaliknya (Sripatmi et al., 2019). Evalusi pembelajaran diperlukan untuk mengetahui sejauh 
mana kemajuan, perkembangan, serta keberhasilan peserta didik setelah melaksanakan proses pembelajaran dalam waktu yang telah di tetapkan.

\subsection{Hasil Korelasi Nilai Ulangan Akhir Semester dan Disposisi Matematika}

Data dari hasil belajar yang diperoleh dari angket dipadukan dengan hasil belajar siswa yang diperoleh dari guru mata pelajaran. Sebelumnya, data hasil belajar siswa dan angket disposisi matematika di uji normalitasnya dengan berbantuan Microsoft Excel. Kedua data tersebut menunjukkan bahwa hasil belajar matematika dan disposisi matematika berdistribusi normal. Selanjutnya untuk melihat hasil belajar dengan disposisi matematika dilakukan pengujian korelasi dengan uji korelasi product moment berbantuan SPSS versi 22 yang digambarkan pada tabel 4.7 berikut:

Tabel 8. Korelasi Hasil Belajar dan Disposisi Matematika

\begin{tabular}{cccc}
\hline & & Hasil Belajar & Disposisi Matematika \\
\hline Hasil Belajar & Pearson & 1 & .141 \\
& Correlation & & .275 \\
& Sig. (2-tailed) & & 62 \\
Disposisi & $\mathrm{N}$ & 62 & 1 \\
Matematika & Pearson & .141 & \\
& Correlation & & 62 \\
& Sig. (2-tailed) & .275 & 62 \\
\hline
\end{tabular}

Berdasarkan hasil perhitungan korelasi didapatkan informasi bahwa nilai koefisien korelasi product momen yaitu 0.141 , hal ini menunjukan bahwa terdapat korelasi tetapi korelasi yang dihasilkan sangat rendah. Secara statistik untuk melihat hubungan secara signifikan yaitu nilai 0.275 dibandingkan nilai kritis korelasi yakni 0.244. Karena $0.275>0.244$ berarti ada korelasi diantara hasil belajar dan disposisi matematika pada penelitian ini.

Hasil ini sejalan dengan penelitian yang dilakukan oleh Ruslan et al., (2017) dan Annajmi (2018). Disposisi matematis merupakan sikap atau kesadaran siswa dalam pembelajaran matematika. Hasil belajar siswa akan menjadi lebih bagus apabila siswa memiliki diposisi matematis. Namun jika dilihat dari nilai ketuntasan yang diperoleh pada tabel 4 , terdapat 44 siswa yang belum tuntas dalam pembelajaran matematika. Terdapat banyak factor yang dapat mempengaruhi hasil belajar siswa. Wahyuningsih (2020) menggolongkan faktor-faktor tersebut menjadi 3 macam yaitu faktor-faktor internal, eksternal dan kurikulum yang digunakan. Faktor internal yaitu faktor yang berasal dari dalam diri sendiri meliputi faktor biologis (jasmaniah) dan faktor psikologis (rohaniah). Herwani (2020:43) Faktor-faktor penyebab Faktor internal sangat mempengaruhi hasil belajar siswa, karena kesehatan jasmani menjadi pendukung untuk kelancaran proses belajar mengajar dan kecerrdasan yang dimilki siswa. Faktor eksternal adalah faktor yang berasal dari luar diri individu yang bersangkutan meliputi 
faktor lingkungan keluarga, faktor lingkungan sekolah, faktor lingkungan masyarakat dan faktor waktu.

Dari hasil penelitian dan pembahasan terkait data hasil belajar dan disposisi matematika siswa, dapat disimpulkan bahwa dalam penelitian ini terdapat korelasi antara hasil beljar siswa dengan disposisi matematika siswa kelas XII IPA di SMAN 7 Mataram.

\section{SIMPULAN}

Berdasarkan hasil penelitian dan pembahasan dapat disimpulkan bahwa:

1. Proses pembelajaran yang dilaksanakan guru berubah dari pembelajaran langsung menjadi pembelajaran dalam jaringan. Dalam proses pembelajaran daring ada beberapa kesulitan yang dialami siswa diantaranya siswa kurang memahami materi yang disampaikan oleh guru baik materi yang disampaikam dalam bentuk pdf atau video yang telah dibagikan. Dalam pelaksanaaan proses pembelajaran daring guru bukan merupakan sumber belajar satu-satunya sehingga siswa aktif mencari sumber referensi belajar yang lain seperti video di youtube dan website. Penilaian hasil belajar dilakukan dengan memberikan tes tertulis dari tes tersebut dihasilkan bahwa tidak terdapat peningkatan hasil belaja siswa selama mengikuti pembelajaran dengan system daring. Terlaksananya pembelajaran daring tidak terlepas dari pengawasan orangtua dan guru.

2. Terdapat korelasi antara nilai ulangan akhir semester dengan disposisi matematika siswa.

\section{REKOMENDASI}

Berdasarkan hasil penelitian terkait analisis pembelajaran daring matematika pada siswa kelas XII IPA SMA Negeri 7 Mataram semester genap tahun pelajaran 2020/2021, saran yang ingin disampaikan adalah sebagai berikut:

1. Berdasarkan hasil penelitian proses pembelajaran daring matematika secara umum berada pada kategori cukup baik, sehingga diharapkan guru dan semua pelaksana pembelajaran di sekolah dapat meningkatkan kualitas pembelajaran daring baik dari segi perencanaan, pelaksanaan pembelajaran, evaluasi dan pengawasan. Bukan hanya guru, orang tua harus juga terlibat secara langsung dalam mengawasi dan memantau siswa saat belajar dari rumah.

2. Bagi mahasiswa, diharapkan kepada seluruh mahasiswa untuk dapat meningkatkan pengetahuan tentang pembelajaran daring untuk dapat mendukung dn menigkatlkan kualitas pembelajaran daring di sekolah.

3. Bagi peneliti lain, diharpakan untuk meniliti analisis pembelajaran daring matematika pada siswa kelas XII IPA SMA Negeri 7 Mataram untuk menambah refrensi penelitian dan evaluasi bagi setiap mahasiswa. 


\section{REFERENSI}

Akbar, P., Hamid, A., Bernard, M., \& Sugandi, A. I. (2018). Analisis kemampuan pemecahan masalah dan disposisi matematik siswa kelas XI SMA Putra Juang dalam materi peluang. Journal Cendekia: Jurnal Pendidikan Matematika, 2(1), 144-153.

Annajmi. (2018). Kontribusi disposisi matematis terhadap prestasi belajar matematika siswa kelas VIII SMPN 3 Tambusai. Journal of Education, Psychology and Counseling, 8(1), 1-8.

Arikunto, S. (2014). Prosedur Penelitian Suatu Pendekatan Praktik. Jakarta: Rineka Cipta.

Azwar, S. (2017). Reliabilitas dan Validitas Edisi 4. Yogyakarta: Pustaka Pelajar.

Desti, H. (2011). Pembelajaran matematika dengan pemecahan masalah untuk menumbuhkembangkan kemampuan berpikir kritis. Prosiding Seminar Nasional Penelitian, Pendidikan Dan Penerapan MIPA, 121-126.

Herwani, F., Azwar, B., \& Yanuarti, E. (2020). Faktor-faktor penyebab rendahnya hasil belajar siswa: studi pada materi quran hadist di MA Ar-Rahma Desa Air Meles Atas. Jurnal AlMau'izhoh E-ISSN, 2(1), 37-49.

Karim, A. (2011). Penerapan metode penemuan terbimbing dalam pembelajaran matematika untuk meningkatkan pemahaman konsep dan kemampuan berpikir kritis siswa sekolah dasar. Jurnal Penelitian Pendidikan, Edisi Khusus (1), 21-32.

Mappeasse, M. Y. (2009). Pengaruh cara dan motivasi belajar terhadap hasil belajar programmable logic controller (PLC) siswa kelas III jurusan listrik SMK Negeri 5 Makassar. Jurnal Medtek, 1(2), 1-6.

Mustaqim, I. (2016). Pemanfaatan augmented reality sebagai media pembelajaran ilmawan. Jurnal Pendidikan Teknologi Dan Kejuruan, 13(2), 174-183. https://doi.org/10.1109/SIBIRCON.2010.5555154

Putria, H., Maula, L. H., \& Uswatun, D. A. (2020). analisis proses pembelajaran dalam jaringan (DARING) masa pandemi Covid- 19 pada guru sekolah dasar. Jurnal Basicedu, 4(4), 861872. https://doi.org/10.31004/basicedu.v4i4.460

Ruslan, Rusli, \& Rusdi. (2017). Pengaruh self-directed learning dan disposisi matematis terhadap hasil belajar matematika siswa. Issues in Mathematics Education, 1(2), 136-142.

Sugiyono. (2014). Metode Penelitian Kuantitatif Kualitatif dan R\&D. Bandung: Alfabeta.

Syarifudin, A. S. (2020). Impelementasi pembelajaran daring untuk meningkatkan mutu pendidikan sebagai dampak diterapkannya social distancing. Metalingua: Jurnal Pendidikan Bahasa Dan Sastra Indonesia Metalingua, 5(1), 31-34. https://doi.org/10.21107/metalingua.v5i1.7072

Utami, R. (2019). Respon mahasiswa terhadap penggunaan google classroom pada mata kuliah psikologi pembelajaran matemtaika. Prisma Prosiding Seminar Nasional Matematika, 2, 408-502.

Wahyuningsih, E. S. (2020). Model Pembelajaran Mastery Learning Upaya Peningkatan Keaktifan Dan Hasil Belajar Siswa. Yogyakarta: Penerbit Deepublish. 